\title{
TOWARDS A DEFINITION OF A BUSINESS PERFORMANCE
} MEASUREMENT SYSTEM

\author{
Franco-Santos, Monica* \\ Kennerley, Mike \\ Micheli, Pietro \\ Martinez, Veronica \\ Mason, Steve \\ Marr, Bernard \\ Gray, Dina \\ Neely, Andy

\begin{abstract}
Centre for Business Performance
Cranfield School of Management

Cranfield University, UK
\end{abstract}

* Corresponding author. Address: Centre for Business Performance, Cranfield School of Management, Cranfield University, Building 31, Cranfield, Bedfordshire, MK43 0AL. Telephone: +44 (0) 1234751122 ext. 2926. Email:

monica.franco@cranfield.ac.uk 


\title{
TOWARDS A DEFINITION OF A BUSINESS PERFORMANCE MEASUREMENT SYSTEM
}

\begin{abstract}
Rationale: Scholars in the field of performance measurement tend to use the term Business Performance Measurement (BPM) systems without explaining exactly what they mean by it. This lack of clarity creates confusion and comparability issues, and makes it difficult for researchers to build on each others' work.
\end{abstract}

Purpose: The purpose of this paper is to identify the key characteristics of a BPM system. We do so by reviewing the different definitions of a BPM system that exist in the literature. Through this work, we aim to open a debate on what are the necessary and sufficient conditions of a BPM system. We also hope to encourage a greater level of clarity in the performance measurement research arena.

Methodology: We review the performance measurement literature using a systematic approach.

Findings: Based on our research, we have proposed a set of conditions of a BPM system from which researchers can choose those which are necessary and sufficient conditions for their studies.

Research implications: The analysis in this paper provides a structure and set of characteristics that researchers could use as a reference framework to define a BPM system for their work, and as a way to define the specific focus of their investigations. More clarity and 
precision around the use of the BPM systems phrase will improve the generalisability and comparability of research in this area.

Keywords: Business performance measurement system, performance measurement, performance management, definition, literature review.

\section{Introduction}

The field of Business ${ }^{1}$ Performance Measurement (BPM) lacks a cohesive body of knowledge (Marr and Schiuma, 2003). Management researchers in areas as diverse as strategy management, operations management, human resources, organisational behaviour, information systems, marketing, and management accounting and control are contributing to the field of performance measurement (Neely, 2002; Marr and Schiuma, 2003; Franco-Santos and Bourne, 2005). While diverse and multi-disciplinary research is appealing, it can also foster complications. These different approaches towards performance measurement have led to numerous definitions of a BPM system ${ }^{2}$, and there is little consensus regarding its main components and characteristics (Dumond, 1994).

The lack of agreement on a definition creates confusion and clearly limits the potential for generalisability and comparability of research in this area. This point is well illustrated by reviewing the BPM system definitions found in the literature. From an operations perspective, a BPM system is mainly perceived as a "set of metrics used to quantify both the efficiency and

\footnotetext{
1 This paper focuses on "business" performance measurement systems, as opposed to "organisational" performance measurement systems. The term "business" is used as a boundary to exclude public and no-profit sector literatures.

2 The paper focuses on the phrase "Business Performance Measurement Systems" as the unit of analysis. It is our assumption that a BPM system is a unique combination of elements. It may be a discrete or explicit system or a collection of existing subsystems; however, it is the combination of these sub-systems that makes it uniquely a BPM system. The term "system" in this phrase is used inconsistently within the literature. Some of the instances of the term may not be recognised as "systems" from some theoretical perspectives. However, rather than attempt to address these semantic and theoretical differences we have accepted all usages of the "system" term as valid in the contexts of the definitions in which they are used. For a more
} 
effectiveness of actions" (Neely et al., 1995); or as the reporting process that gives feedback to employees on the outcome of actions (Bititci et al., 1997). From a strategic control perspective, two different aspects of a BPM system can be identified. On one hand, it reflects the procedures used to cascade down those performance metrics used to implement the strategy within the organisation (Gates, 1999). On the other hand, a BPM system is the system that not only allows an organisation to cascade down its business performance measures, but also provides it with the information necessary to challenge the content and validity of the strategy (Ittner et al, 2003). From a management accounting perspective, a BPM system is considered to be synonymous with management planning and budgeting (Otley, 1999).

The main purpose of this paper is not to provide another definition; rather, it is to define the key characteristics of a BPM system, based on a review of the definitions found in the literature. To define a concept, it is crucial to identify the necessary and sufficient ${ }^{3}$ conditions for its existence (Brennan, 2003). This article, therefore, seeks to encourage a debate in the academic and practitioner communities regarding the main elements of business performance measurement systems. This reflective dialogue will hopefully lead to a shared and comprehensive definition of a BPM system.

In terms of more immediate implications for the research arena, we believe that greater clarity on what a BPM system comprises could substantially improve the comparability and generalisability of the research conducted in the field of business performance measurement. As it stands, scholars utilise the phrase "BPM system" without specifying which elements they are focusing on, and which conditions are (or have to be) present in the empirical contexts they

comprehensive discussion and definitions of the term "system", please refer to Checkland (1999); Klir (1991) or Marion (1999).

3 A "necessary" condition is one without which something cannot be what it is. For example, if something is not a plant, it cannot be a flower. So being a plant is a necessary condition for being a flower. A "sufficient" condition specifies one way of being that thing. For example, a daisy is one type of flower; however, not being a daisy does not mean that something is not a flower, it could be a rose . So being a "daisy" could be a sufficient condition for being a flower (Brennan, 2003). 
study. In order to ensure greater understanding of the research carried out in this field, and the possibility of comparing findings appropriately, it is important that researchers make explicit statements of which conditions are considered necessary and/or sufficient for the existence of BPM systems in each study. Furthermore, we believe that comparability, based on thorough understanding of what every piece of research entails, is a fundamental requirement to contribute to both theory and practice, and ultimately lead to evidence-based management (cf. Rousseau, 2006; Pfeffer \& Sutton, 2006).

This article is structured as follows. Firstly, it provides a comprehensive review and analysis of the different definitions of BPM systems that can be found in performance measurement literature. Secondly, based on our analysis of the definitions of BPM systems, it shows the different elements that a BPM system may have. Thirdly, our findings are discussed and a set of necessary and sufficient conditions of a BPM system are presented. Finally, limitations and conclusions of our study are outlined.

\section{Methodology}

Definitions of BPM systems have been proposed by scholars coming from a number of disciplines. In order to scope the literature review, we followed a systematic method. Firstly, we used two different electronic databases to search for key references on the area of performance measurement. These electronic databases were ABI-Proquest, and EBSCO. We searched those databases using the keyword "performance measurement system*"4 . In the former database we found 2041 references; in the latter, 239. Secondly, we selected the relevant studies coming from these databases. Relevant studies were those that fulfilled the following

\footnotetext{
4 A truncation character, *, is used to find articles containing words with the same root. Therefore, a search for performance measurement system* will find articles containing the words "performance measurement system" and "performance
} 
selection criteria: (1) research looking at business performance measurement; (2) research published in peer reviewed scholarly journals; (3) private sector research; and (4) post-1980 research. This last criterion was included because of the change in perspective that took place in the 1980 s, for which performance measurement moved away from having a pure financial focus to include more comprehensive business characteristics (e.g. Kaplan, 1983).

Out of the total number of journal articles found, 205 passed our selection criteria. Subsequently, we read those articles looking for BPM system definitions. Whilst reading those articles, notes were taken about potential cross-references that could be relevant for our research. Through this process another 132 documents, including not only journal articles but also books, books chapters, conference papers and working papers, were identified and included. In total, more than 300 documents were reviewed, but the research team came across only seventeen different definitions of BPM systems.

In order to assess how widely known and relevant the definitions found in the literature were, we conducted a citation analysis of the papers containing each definition. We used three different databases to carry out this analysis ${ }^{5}$ : the Social Science Citation Index, Scopus and Google Scholar. It must be noted that this type of analysis has a random duplication effect. This means that the citation of a paper in one database can be found in the other two databases; thus, the summary of citations per paper across the three databases cannot be performed. Clearly the citation analysis we have conducted can be criticised on the grounds that citations are made to papers rather than definitions. However, we have assumed that the most frequently quoted

measurement systems"; but also "business performance measurement systems", "strategic performance measurement systems", etc.

5 Three databases were chosen in order to enhance the rigour of our citation analysis. Scopus was selected because it covers 14,200 publications (including conference proceedings); the Social Citation Index was selected because traditionally it has been the point of reference for this type of research analysis; finally, the Google Scholar was selected because it is the only database that covers the citation of books. 
articles are amongst the most widely read and hence, if frequently cited papers contain

definitions, these too are likely to be reasonably well known.

\section{BPM system definitions}

The definitions selected from the literature and the results of the citation analysis are presented in Table 1.

Table 1: Selected definitions of BPM systems

\begin{tabular}{|c|c|c|c|c|c|}
\hline \multirow[b]{2}{*}{ Author } & \multirow[b]{2}{*}{ Date } & \multirow[b]{2}{*}{ Definition } & \multicolumn{3}{|c|}{ Citation Analysis } \\
\hline & & & $\begin{array}{l}\text { Social } \\
\text { Science } \\
\text { Citation } \\
\text { Index } \\
\end{array}$ & Scopus & $\begin{array}{l}\text { Google } \\
\text { Scholar }\end{array}$ \\
\hline Atkinson & 1998 & 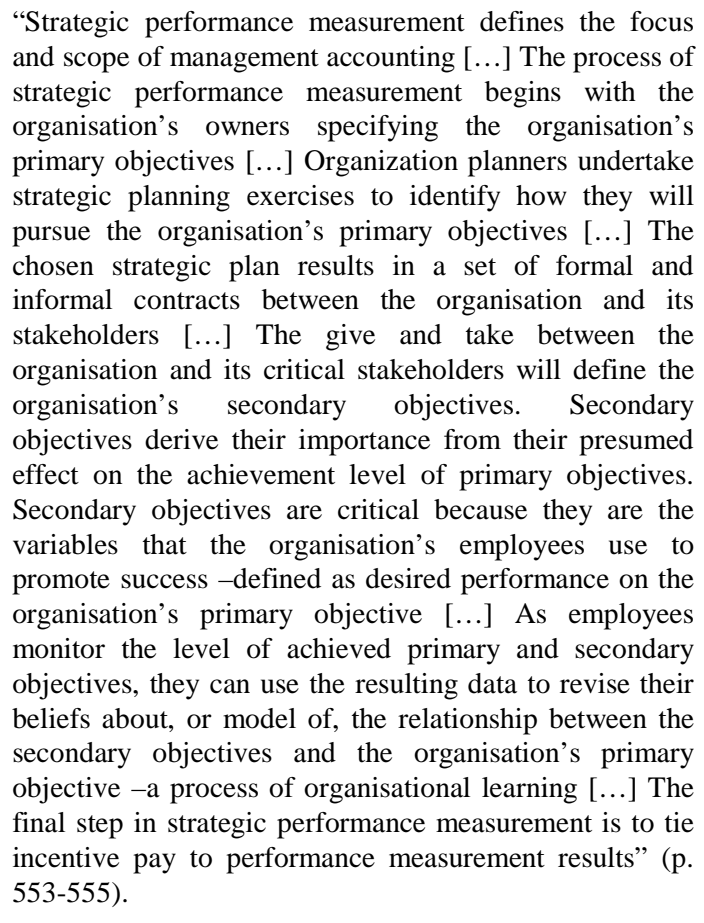 & 0 & 4 & 14 \\
\hline $\begin{array}{l}\text { Atkinson, } \\
\text { Waterhouse \& } \\
\text { Wells }\end{array}$ & 1997 & $\begin{array}{l}\text { "Our approach to performance measurement focuses on } \\
\text { one output of strategic planning: senior management's } \\
\text { choice of the nature and scope of the contracts that it } \\
\text { negotiates, both explicitly and implicitly, with its } \\
\text { stakeholders. The performance measurement system is } \\
\text { the tool the company uses to monitor those contractual } \\
\text { relationships" (p. 26) }\end{array}$ & 25 & 0 & 128 \\
\hline
\end{tabular}




\begin{tabular}{|c|c|c|c|c|c|}
\hline \multirow[b]{2}{*}{ Author } & \multirow[b]{2}{*}{ Date } & \multirow[b]{2}{*}{ Definition } & \multicolumn{3}{|c|}{ Citation Analysis } \\
\hline & & & $\begin{array}{l}\text { Social } \\
\text { Science } \\
\text { Citation } \\
\text { Index } \\
\end{array}$ & Scopus & $\begin{array}{l}\text { Google } \\
\text { Scholar }\end{array}$ \\
\hline $\begin{array}{l}\text { Bititci, Carrie } \\
\& \text { Mcdevitt }\end{array}$ & 1997 & $\begin{array}{l}\text { "A performance measurement system is the information } \\
\text { system which is at the heart of the performance } \\
\text { management process and it is of critical importance to the } \\
\text { effective and efficient functioning of the performance } \\
\text { management system" (p. 533) }\end{array}$ & 15 & 3 & 57 \\
\hline $\begin{array}{l}\text { Bourne, } \\
\text { Neely, Mills \& } \\
\text { Platts }\end{array}$ & 2003 & $\begin{array}{l}\text { "A business performance measurement system refers to } \\
\text { the use of a multi-dimensional set of performance } \\
\text { measures for the planning and management of a } \\
\text { business" (p. 4) }\end{array}$ & - & 0 & 11 \\
\hline $\begin{array}{l}\text { Forza \& } \\
\text { Salvador }\end{array}$ & 2000 & $\begin{array}{l}\text { "A performance measurement system is an information } \\
\text { system that supports managers in the performance } \\
\text { management process mainly fulfilling two primary } \\
\text { functions: the first one consists in enabling and } \\
\text { structuring communication between all the organisational } \\
\text { units (individuals, teams, processes, functions, etc.) } \\
\text { involved in the process of target setting. The second one } \\
\text { is that of collecting, processing and delivering } \\
\text { information on the performance of people, activities, } \\
\text { processes, products, business units, etc." (p.359). }\end{array}$ & 1 & 4 & 4 \\
\hline Gates & 1999 & $\begin{array}{l}\text { "A strategic performance measurement system translates } \\
\text { business strategies into deliverable results. Combine } \\
\text { financial, strategic and operating measures to gauge how } \\
\text { well a company meets its targets" (p. 4). }\end{array}$ & - & - & 6 \\
\hline $\begin{array}{l}\text { Ittner., Larcker } \\
\text { \& Randall }\end{array}$ & 2003 & $\begin{array}{l}\text { "A strategic performance measurement system: (1) } \\
\text { provides information that allows the firm to identify the } \\
\text { strategies offering the highest potential for achieving the } \\
\text { firm's objectives, and (2) aligns management processes, } \\
\text { such as target setting, decision-making, and performance } \\
\text { evaluation, with the achievement of the chosen strategic } \\
\text { objectives" (p.715). }\end{array}$ & - & 14 & 25 \\
\hline $\begin{array}{l}\text { Kaplan \& } \\
\text { Norton }\end{array}$ & 1996 & $\begin{array}{l}\text { A balanced scorecard }{ }^{6} \text { is a comprehensive set of } \\
\text { performance measures defined from four different } \\
\text { measurement perspectives (financial, customer, internal, } \\
\text { and learning and growth) that provides a framework for } \\
\text { translating the business strategy into operational terms ( } \mathrm{p} \text {. } \\
\text { 55) }\end{array}$ & 23 & 42 & 130 \\
\hline $\begin{array}{l}\text { Kerssens-van } \\
\text { Drongelen \& } \\
\text { Fisscher }\end{array}$ & 2003 & $\begin{array}{l}\text { "Performance measurement and reporting takes place at } 2 \\
\text { levels: (1) company as a whole, reporting to external } \\
\text { stakeholders, (2) within the company, between managers } \\
\text { and their subordinates. At both levels there are } 3 \text { types of } \\
\text { actors: (a) evaluators (e.g. managers, external } \\
\text { stakeholders), (b) evaluatee (e.g. middle managers, } \\
\text { company), (c) assessor, which is the person or institution }\end{array}$ & - & 0 & 2 \\
\hline
\end{tabular}




\begin{tabular}{|c|c|c|c|c|c|}
\hline \multirow[b]{2}{*}{ Author } & \multirow[b]{2}{*}{ Date } & \multirow[b]{2}{*}{ Definition } & \multicolumn{3}{|c|}{ Citation Analysis } \\
\hline & & & $\begin{array}{l}\text { Social } \\
\text { Science } \\
\text { Citation } \\
\text { Index } \\
\end{array}$ & Scopus & $\begin{array}{l}\text { Google } \\
\text { Scholar }\end{array}$ \\
\hline & & $\begin{array}{l}\text { for all of an organization's performance metrics and to } \\
\text { disseminate the results throughout the organization as } \\
\text { needed" (p. B6-2\&3) }\end{array}$ & & & \\
\hline Neely & 1998 & $\begin{array}{l}\text { A performance measurement system enables informed } \\
\text { decisions to be made and actions to be taken because it } \\
\text { quantifies the efficiency and effectiveness of past actions } \\
\text { through the acquisition, collation, sorting, analysis, } \\
\text { interpretation, and dissemination of appropriate data. } \\
\text { Organizations measure their performance in order to } \\
\text { check their position (as a means to establish position, } \\
\text { compare position or benchmarking, monitor progress), } \\
\text { communicate their position (as a means to communicate } \\
\text { performance internally and with the regulator), confirm } \\
\text { priorities (as a means to manage performance, cost and } \\
\text { control, focus investment and actions), and compel } \\
\text { progress (as a means of motivation and rewards) (p.5-6) }\end{array}$ & 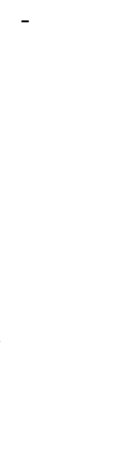 & - & 29 \\
\hline $\begin{array}{l}\text { Neely, } \\
\text { Gregory \& } \\
\text { Platts }\end{array}$ & 1995 & $\begin{array}{l}\text { A performance measurement system (PMS) is "the set of } \\
\text { metrics used to quantify both the efficiency and } \\
\text { effectiveness of actions" (p. 81). A PMS can be } \\
\text { examined at three different levels. (1) At the level of } \\
\text { individual performance measures, the PMS can be } \\
\text { analysed by asking questions such as: What performance } \\
\text { measures are used? What are they used for? How much } \\
\text { do they cost? What benefit do they provide? (2) At the } \\
\text { next higher level, the performance measurement system } \\
\text { as an entity, can be analysed by exploring issues such as: } \\
\text { Have all the appropriate elements (internal, external, } \\
\text { financial, nonfinancial) been covered? Have measures } \\
\text { which relate to the rate of improvement been introduced? } \\
\text { Have measures which relate to both the long and the } \\
\text { short term objectives of the business been introduced? } \\
\text { Have the measures been integrated, both vertically and } \\
\text { horizontally? Do any of the measures conflict with one } \\
\text { another? (3) And at the level of the relationship between } \\
\text { the performance measurement system and the } \\
\text { environment within which it operates. At this level the } \\
\text { system can be analysed by assessing: Whether the } \\
\text { measures reinforce the firm's strategies; whether the } \\
\text { measures match the organization's culture; whether the } \\
\text { measures are consistent with the existing recognition and } \\
\text { reward structure; whether some measures focus on } \\
\text { customer satisfaction; whether some measures focus on } \\
\text { what the competition is doing (p. ) }\end{array}$ & 42 & 107 & 234 \\
\hline Rogers & 1990 & $\begin{array}{l}\text { BPM systems can be characterized as "an integrated set } \\
\text { of planning and review procedures which cascade down } \\
\text { through the organization to provide a link between each } \\
\text { individual and the overall strategy of the organization." } \\
\text { (in Smith \& Goddard, 2002, p. 248) }\end{array}$ & - & 0 & 24 \\
\hline Otley & 1999 & $\begin{array}{l}\text { "System that provides the information that is intended to } \\
\text { be useful to managers in performing their jobs and to }\end{array}$ & - & 50 & 136 \\
\hline
\end{tabular}




\begin{tabular}{|c|c|c|c|c|c|}
\hline \multirow[b]{2}{*}{ Author } & \multirow[b]{2}{*}{ Date } & \multirow[b]{2}{*}{ Definition } & \multicolumn{3}{|c|}{ Citation Analysis } \\
\hline & & & $\begin{array}{l}\text { Social } \\
\text { Science } \\
\text { Citation } \\
\text { Index } \\
\end{array}$ & Scopus & $\begin{array}{l}\text { Google } \\
\text { Scholar }\end{array}$ \\
\hline & & $\begin{array}{l}\text { assist organizations in developing and maintaining viable } \\
\text { patterns of behaviour. Any assessment of the role of such } \\
\text { information requires consideration of how managers } \\
\text { make use of the information being provided to them" (p. } \\
\text { 364). Main components of a PMS: (1) objectives, (2) } \\
\text { strategy, (3) targets, (4) rewards, (5) information flows } \\
\text { (feedback and feed-forward). }\end{array}$ & & & \\
\hline
\end{tabular}

The definitions of BPM system extracted from the reviewed literature demonstrate the diversity of the subject and the lack of consensus on a definition. Each definition provides a different perspective on the concept, and no two definitions agree on the precise characteristics. Each of the cited authors defines BPM system from a different perspective, and does so using different types of characteristics to derive their definition. Initial analysis of the definitions shows that the basis of the definitions is one or a combination of (1) the features of the BPM system; (2) the role(s) that the BPM system plays; and (3) the processes that are part of the BPM system. To be more precise, the features of a BPM system are properties or elements which make up the BPM system; the roles of a BPM system are the purposes or functions that are performed by the BPM system; and the processes of a BPM system are the series of actions that combine together to constitute the BPM system.

In order to identify the key characteristics of a BPM system, the seventeen definitions found in the literature were content analysed. Therefore, we conducted three different analyses. Firstly, the content of the seventeen definitions was examined in order to identify the main features of a BPM system. Secondly, the content of the definitions was examined to identify the roles that a BPM system plays in an organisation. Finally, the content of the definitions was examined in order to clarify the processes that take place within a BPM system. Each content analysis was conducted by two different teams of researchers in order to increase the validity of 
the analysis. The outputs from both teams were shared and discussed, and a definite list of BPM system characteristics was agreed.

\section{Characteristics of a BPM system}

The characteristics obtained as a result of the content analysis are presented in Tables 2, 3 and 4 . The left hand column of each table describes the characteristic found in the definitions with the columns showing in which of the definitions these characteristics can be found ${ }^{7}$.

\footnotetext{
${ }^{7}$ The letter " $\mathrm{X}$ " is included if the definition provided refers to the feature, role or process stated in the first column.
} 
Table 2: Main FEATURES of BPM systems

\begin{tabular}{|c|c|c|c|c|c|c|c|c|c|c|c|c|c|c|c|c|c|c|c|}
\hline & & 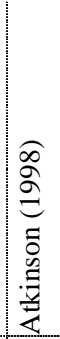 & 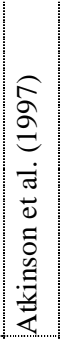 & 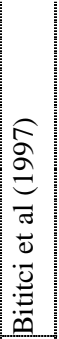 & 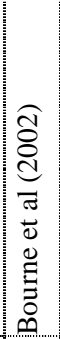 & 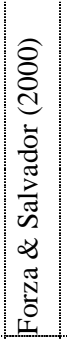 & 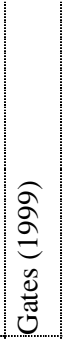 & 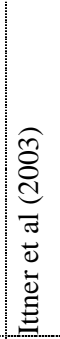 & 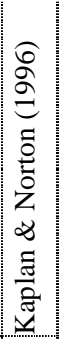 & 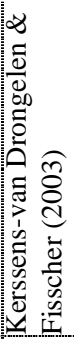 & 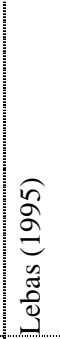 & 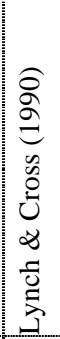 & 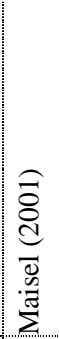 & 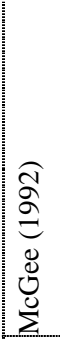 & 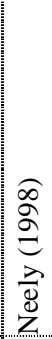 & $\begin{array}{l}\hat{2} \\
2 \\
\frac{\pi}{\pi} \\
\frac{\pi}{0} \\
\frac{2}{0} \\
\frac{\pi}{2}\end{array}$ & $\frac{\widehat{\partial}}{2}$ & 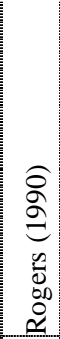 & 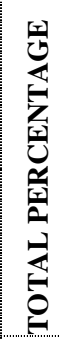 \\
\hline 1. & $\begin{array}{l}\text { Performance } \\
\text { Measures (including } \\
\text { features such as Multi- } \\
\text { dimensional, } \\
\text { leading/lagging, } \\
\text { efficiency/effectiveness, } \\
\text { internal /external, } \\
\text { vertically \& } \\
\text { horizontally integrated, } \\
\text { multi-level) }\end{array}$ & & & & $\mathrm{x}$ & & $\mathrm{x}$ & & $\mathrm{x}$ & & $x$ & $x$ & & $x$ & $x$ & $x$ & $x$ & & 53 \\
\hline 2. & $\begin{array}{l}\text { Objectives / Goals } \\
\text { (often referring to } \\
\text { strategic objectives) }\end{array}$ & $\mathrm{x}$ & & & & & & $\mathrm{x}$ & $\mathrm{x}$ & & & & $x$ & $x$ & & & $x$ & & 35 \\
\hline 3. & $\begin{array}{l}\text { Supporting } \\
\text { infrastructure (which } \\
\text { can include data } \\
\text { acquisition, collation, } \\
\text { sorting, analysis, } \\
\text { interpretation, and } \\
\text { dissemination (Neely, } \\
\text { 1998)) }\end{array}$ & $\mathrm{x}$ & & & & $\mathrm{x}$ & & & & $\mathrm{x}$ & & & & $x$ & $x$ & & & & 29 \\
\hline 4. & Targets & & & & & $\mathrm{x}$ & $x$ & $\mathrm{x}$ & & & & & & & & & $x$ & & 24 \\
\hline 5. & Causal models & $\mathrm{x}$ & & & & & & & & & $\mathrm{x}$ & & & & & & & & 12 \\
\hline 6. & Hierarchy/cascade & & & & & & & & & & & & & & & $\mathrm{x}$ & & $\mathrm{x}$ & 12 \\
\hline 7. & Performance contract & $\mathrm{x}$ & $x$ & & & & & & & & & & & & & & & & 12 \\
\hline & Rewards & $x$ & & & & & & & & & & & & & & & $\mathrm{x}$ & & 12 \\
\hline
\end{tabular}


Table 3: Main ROLES of BPM systems

\begin{tabular}{|c|c|c|c|c|c|c|c|c|c|c|c|c|c|c|c|c|c|c|}
\hline & 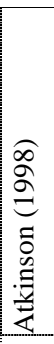 & 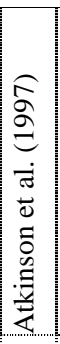 & 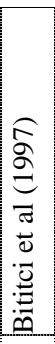 & 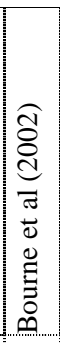 & 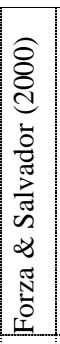 & 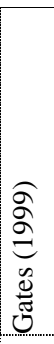 & 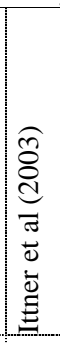 & 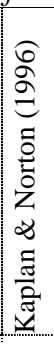 & 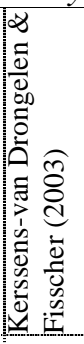 & 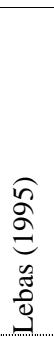 & 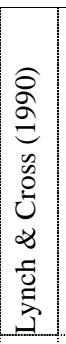 & 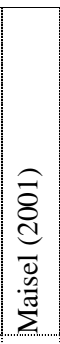 & 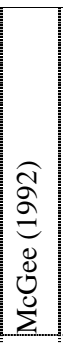 & 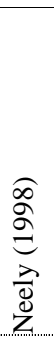 & 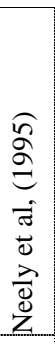 & 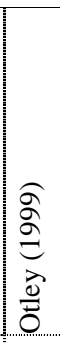 & 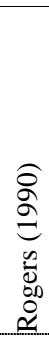 & 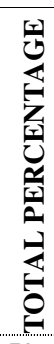 \\
\hline $\begin{array}{l}\text { 1. Strategy } \\
\text { implementation/ } \\
\text { execution }\end{array}$ & $\mathrm{x}$ & & & & & $x$ & $\mathrm{x}$ & $\mathrm{x}$ & & & $\mathrm{x}$ & $\mathrm{x}$ & $\mathrm{x}$ & $\mathrm{x}$ & & $\mathrm{x}$ & $\mathrm{x}$ & 59 \\
\hline $\begin{array}{l}\text { 2. Focus attention/ } \\
\text { provide alignment }\end{array}$ & $\mathrm{x}$ & & & & & & $\mathrm{x}$ & & & & & $\mathrm{x}$ & $\mathrm{x}$ & $\mathrm{x}$ & & $\mathrm{x}$ & $\mathrm{x}$ & 41 \\
\hline $\begin{array}{l}\text { Internal } \\
\text { communication } \\
\text { (communicating } \\
\text { performance, and } \\
\text { priorities / objectives) }\end{array}$ & & & $\mathrm{x}$ & & $\mathrm{x}$ & & & & $\mathrm{x}$ & & $\mathrm{x}$ & & & $\mathrm{x}$ & $\mathrm{x}$ & $\mathrm{x}$ & & 41 \\
\hline $\begin{array}{l}\text { 4. Measure performance/ } \\
\text { performance } \\
\text { evaluation }\end{array}$ & & & & & & & & $\mathrm{X}$ & $\mathrm{X}$ & $\mathrm{x}$ & & $\mathrm{X}$ & $\mathrm{x}$ & $\mathrm{x}$ & $\mathrm{x}$ & & & 41 \\
\hline 5. Monitor progress & $\mathrm{x}$ & $\mathrm{X}$ & & & & & & & & & & $\mathrm{X}$ & $\mathrm{X}$ & $\mathrm{x}$ & $\mathrm{X}$ & & & 35 \\
\hline 6. Planning & & & & $\mathrm{x}$ & & & & & & & & $\mathrm{x}$ & $\mathrm{x}$ & & & & $\mathrm{x}$ & 29 \\
\hline $\begin{array}{ll}\text { 7. } & \begin{array}{l}\text { External } \\
\text { communication }\end{array}\end{array}$ & & & & & & & & & $\mathrm{X}$ & & & & $\mathrm{x}$ & $\mathrm{x}$ & & & & 24 \\
\hline 8. Rewards & $\mathrm{x}$ & & & & & & & & & & & & & $\mathrm{x}$ & & $\mathrm{x}$ & & 18 \\
\hline $\begin{array}{l}\text { 9. Performance } \\
\text { Improvement }\end{array}$ & & & & & & & & & & & & & & $\mathrm{x}$ & $\mathrm{X}$ & & & 18 \\
\hline $\begin{array}{ll}\text { 10. } & \begin{array}{l}\text { Managing } \\
\text { Relationships }\end{array}\end{array}$ & $\mathrm{X}$ & $\mathrm{X}$ & & & & & & & & & & & & & & & & 12 \\
\hline 11. Feedback & & & & & $\mathrm{x}$ & & & & & & & & & & & $\mathrm{x}$ & & 12 \\
\hline 12. Double-loop Learning & $\mathrm{x}$ & & & & & & & & & $\mathrm{x}$ & & & & & & & & 12 \\
\hline 13. Strategy formulation & & & & & & & & & & & & & & $\mathrm{x}$ & & & & 6 \\
\hline 14. Benchmarking & & & & & & & & & & & & & & $\mathrm{x}$ & & & & 6 \\
\hline $\begin{array}{l}\text { 15. Compliance with } \\
\text { regulations }\end{array}$ & & & & & & & & & & & & & & $\mathrm{x}$ & & & & 6 \\
\hline 16. Control & & & & & & & & & & & & $\mathrm{X}$ & & & & & & 6 \\
\hline 17. Influence Behaviour & & & & & & & & & & & & & & & & $\mathrm{X}$ & & 6 \\
\hline
\end{tabular}

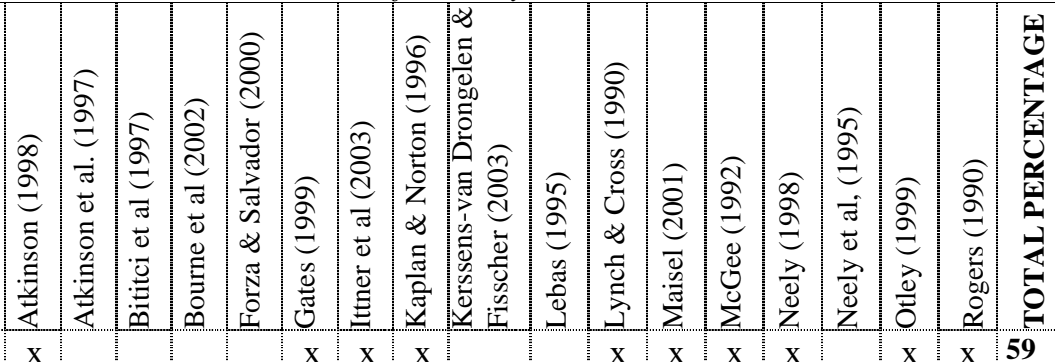




\begin{tabular}{|c|c|c|c|c|c|c|c|c|c|c|c|c|c|c|c|c|c|c|}
\hline & 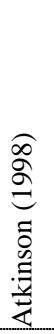 & 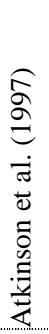 & 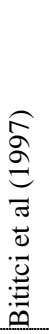 & 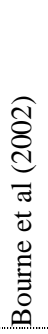 & 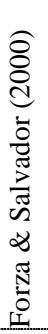 & 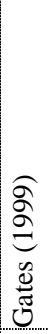 & 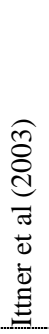 & 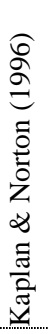 & 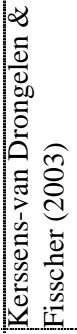 & $\begin{array}{l}\tilde{2} \\
\stackrel{2}{=} \\
\tilde{0} \\
\stackrel{0}{0}\end{array}$ & 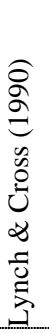 & 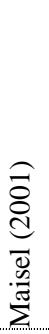 & 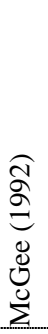 & $\begin{array}{l}\stackrel{\infty}{2} \\
\stackrel{2}{2} \\
\frac{0}{\mathbb{d}} \\
z\end{array}$ & 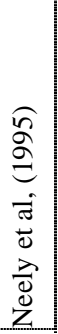 & $\begin{array}{l}\stackrel{\widehat{\sigma}}{\sigma} \\
\frac{\overrightarrow{0}}{\tilde{0}}\end{array}$ & 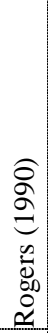 & 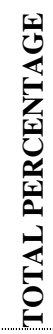 \\
\hline $\begin{array}{l}\text { 1. Information provision } \\
\text { (feed-forward \& } \\
\text { feedback) }\end{array}$ & $\mathrm{x}$ & & $\mathrm{x}$ & & $\mathrm{x}$ & & & & $\mathrm{X}$ & $\mathrm{x}$ & $\mathrm{X}$ & & $\mathrm{x}$ & $\mathrm{x}$ & & & $\mathrm{X}$ & 53 \\
\hline $\begin{array}{l}\text { Measures design/ } \\
\text { selection }\end{array}$ & & & & & & & & $\mathrm{X}$ & & $\mathrm{X}$ & & & $\mathrm{X}$ & $\mathrm{X}$ & $\mathrm{X}$ & & & 29 \\
\hline 3. Data capture & $\mathrm{X}$ & & & & $\mathrm{X}$ & & & & & & $\mathrm{X}$ & & $\mathrm{X}$ & $\mathrm{X}$ & & & & 29 \\
\hline 4. Target setting & & & & & $\mathrm{X}$ & & $\mathrm{X}$ & & & & & & & & & $\mathrm{X}$ & & 18 \\
\hline 5. Rewards & $\mathrm{X}$ & & & & & & & & & & & & & $\mathrm{X}$ & & $\mathbf{X}$ & & 18 \\
\hline $\begin{array}{l}\text { Identify stakeholders } \\
\text { needs \& wants }\end{array}$ & $\mathrm{X}$ & $\mathrm{X}$ & & & & & & & & & & & & & & & & 12 \\
\hline $\begin{array}{l}\text { 7. } \\
\begin{array}{l}\text { Strategic objectives } \\
\text { specification }\end{array}\end{array}$ & $\mathrm{X}$ & & & & & & & & & & & & & & & $\mathrm{X}$ & & 12 \\
\hline 8. Data analysis & & & & & & & & & & & $\mathrm{x}$ & & & $\mathrm{X}$ & & & & 12 \\
\hline 9. Decision making & & & & & & & $\mathbf{X}$ & & & & & & & $\mathrm{X}$ & & & & 12 \\
\hline $\begin{array}{l}\text { 10. Performance } \\
\text { evaluation }\end{array}$ & & & & & & & $\mathrm{X}$ & & $\mathrm{X}$ & & & & & & & & & 12 \\
\hline 11. Interpretation & & & & & & & & & & & & & & $\mathrm{X}$ & & & & 6 \\
\hline 12. Review procedures & & & & & & & & & & & & & & & & & $\mathrm{X}$ & 6 \\
\hline 13. Planning & & & & & & & & & & & & & & & & & $\mathrm{X}$ & \\
\hline
\end{tabular}

\section{Discussion}

This research has examined a set of BPM system definitions found in the literature on performance measurement in the private sector. The main purpose of looking at BPM system definitions was to identify the characteristics that are seen as necessary and/or sufficient for the existence of a BPM system. After conducting a methodical literature review and reading over 300 documents (including journal articles, books, conference papers and working papers), we found only seventeen definitions of the BPM system concept. This finding has critical implications for the performance measurement literature. It suggests that the majority of researchers in this field do not explicitly define what they are referring to when they use the 
phrase BPM system. This means that it is difficult for readers to know exactly what these researchers are investigating, and hence compare different studies, generalise and draw conclusions about the body of research in the field.

Clear understanding and comparability of research is important due to the diversity of approaches used to look at performance measurement in organizations. This heterogeneity is reflected in the variety of characteristics extracted from the set of definitions analysed. BPM systems have been described according to their features, roles and processes, but none of the definitions has a common or consistent set of characteristics. Thus, although researchers may assume that there is a common understanding of what is and is not a BPM system, this study suggests that this assumption is flawed. As a result, it could be argued that if the performance measurement field is to develop and become more relevant to theory and practice, then researchers need to be more specific and explicit about the characteristics of the systems they are studying. Otherwise, generalisability and comparability of research will be difficult to judge, and this has strong implications regarding the development of this field of research and its impact on practice.

As previously mentioned, there is little agreement concerning the characteristics of a BPM system. However, we found some consensus about two features of BPM systems: 53\% of the authors mention "performance measures"; and 35\% suggest "objectives/goals" as features of BPM systems. There is also some consensus regarding five roles of BPM systems: 59\% consider "strategy implementation/execution"; $41 \%$ suggest "focus attention/provide alignment", "internal communication" and "measure performance/performance evaluation"; and 35\% of authors mention "progress monitoring" as roles of BPM systems. Finally, there is some agreement concerning one process of BPM systems. That is "information provision", which has been cited by $53 \%$ of the authors. The remaining characteristics found in the 
definitions are used by five or fewer people. It is interesting to note that the majority of the authors concentrate on only a few elements from the list. Neely (1998) is the only author to cover many of the elements together (citing $51 \%$ of the elements in his definition).

As discussed in the introduction, in order to define something it is necessary to specify its necessary and sufficient conditions. As we have stated, the main intention of this paper is not to create a new definition, but to identify the characteristics that researchers might include as necessary or sufficient conditions when defining the BPM systems they are going to use in their investigations. Thus, which characteristics of a BPM system could be considered key or necessary and which elements of a BPM system could be considered sufficient? This question is addressed in the next three sections, building on our findings, and on the knowledge and experience we have in the field of performance measurement.

\section{Features of a BPM system}

Following the analyses of the definitions of a BPM system, we could argue that there are only two necessary features: "performance measures" and "supporting infrastructure". That measures (also referred to as metrics or data in the definitions) are a necessary requirement for a BPM system to exist is clearly a tautology. This perhaps explains why so many authors neglect to mention them in their definitions. Although the existence of measures is taken as a given, there is no such agreement on the nature and design of those measures. There has long been a discussion about the need to include other dimensions of performance than just financial (Drucker, 1954; Goold \& Quinn, 1990; Johnson \& Kaplan, 1987); however there is no consensus on what the other dimensions should be, and in fact the evidence that there should be 'balance' in the measures used is far from conclusive (Kennerley \& Bourne, 2003). As such, it is impossible to define generic types or characteristics of measures that should be included in any definition of a BPM system. 
A supporting infrastructure can vary from very simplistic manual methods of recording data to sophisticated information systems and supporting procedures which might include data acquisition, collation, sorting, analysis, interpretation, and dissemination (Neely, 1998), and the human resources required to support them (Kerssens-van Drongelen \& Fisscher, 2003). A supporting infrastructure may be an explicit and instantly recognisable system and a set of processes that have been implemented as part of a discrete BPM system, or might be separate activities within other performance management processes that the BPM system functions. Taking into account these two conditions, it could be argued that if a piece of research only used performance measures and supporting infrastructure as necessary features of a BPM system, then a computerised Balanced Scorecard IT system would be enough evidence of the existence of the necessary features, and hence a PMS.

One feature that could be problematic as regards to its necessary or sufficient nature is "goals" (often referred to as "strategic goals"). A common purpose for implementing a BPM system is to achieve some organisational goals and, very often, this relates to strategic goals. For example, one of the stated objectives of implementing a Balanced Scorecard-based measurement system is often to achieve an organisation's strategic objectives. This could be expected, given the relationship between goals and organizational viability (Deming, 1982, Feurer and Chaharbaghi, 1995). Given the recent emphasis on strategic performance measurement systems, it is not surprising that many of the definitions talk about linking measures to strategy or strategic objectives. However, there are measurement systems within businesses that will only have operational goals, which may or may not be implicitly or explicitly linked to strategy. Furthermore, a set of financial accounts is undoubtedly a business performance report, and hence the system that produced it is a business performance measurement system. Nevertheless, there is no specific performance objective, strategic or otherwise, to which these accounts are necessarily linked. 


\section{Roles of BPM systems}

Seventeen different roles of a BPM system have been identified. However, we argue that the only necessary role is the use of BPM systems to "measure performance". The consideration of this role as necessary is again a tautology. This is probably the reason why many authors do not mention it in their definition. We accept this despite the fact that a number of studies argue that significant value is gained from the process of designing performance measures, regardless of the implementation and data collection phases (Neely et al, 2000). The rest of the roles extracted from our analysis can be considered context specific. Therefore, it is extremely important that researchers clarify in their studies the different roles that the BPM system plays in the firms they are investigating.

It is interesting to note that organizational learning (Senge, 1990) is not directly quoted as a BPM system role, although several definitions refer to some elements of the learning process. This is surprising, given the centrality of the learning perspective in the Balanced Scorecard (Sim and Koh, 2001) and in many other management areas such as strategy (Fuerer and Chaharbaghi, 1995). Our opinion is that, although it is possible to design, maintain and use a BPM system without organizational learning occurring, such an outcome is extremely unlikely. One of the primary effects of the kind of 'self-analysis' undertaken during system design is improved knowledge of the organization, and given the iterative and cumulative impact of experience with a BPM system, it is highly likely that learning will occur (Neely et al, 2000).

In order to help researchers in the process of identifying and selecting the roles of BPM systems that will be the focus of their investigations, we propose five different categories of BPM system roles. These are: (1) "measure performance", this category encompasses the role of monitor progress and measure performancelevaluate performance; (2) "strategy 
management", this category comprises the roles of planning, strategy formulation, strategy implementation /execution, and focus attention/provide alignment; (3) "communication", which comprises the roles of internal and external communication, benchmarking and compliance with regulations; (4) "influence behaviour", this category encompasses the roles of rewarding or compensating behaviour, managing relationships and control; and (5) "learning and improvement" that comprises the roles of feedback, double-loop learning and performance improvement.

\section{Processes of BPM systems}

Based on our analysis, BPM systems include twelve different processes, out of which we believe that only three could be considered necessary. These are: "information provision" "measure design and selection" and "data capture" (regardless of how the data capture is done). If a company does not have a specific process for selecting the measures it is going to use to assess its performance (even if those measures are imposed by external stakeholders); if it does not have a process for capturing the data to calculate its selected performance measures; and if it does not have a process to distribute the results of the performance measurement exercise (even if it is with a simple Excel spreadsheet); thus, it could be argued that this company does not have a BPM system.

It is important to highlight that even though we consider these three processes as the only necessary processes, it is highly unlikely that some kind of "data analysis" or manipulation will not be done to sort the data into a meaningful and usable format. Without even limited manipulation the measurement process will be of no value whatsoever. In our opinion, the rest of the processes included in Table 4 cannot be considered necessary as they are not critical for the functioning of a BPM system. They are probably beneficial for the effectiveness of a BPM system, but this discussion is out of the scope of this paper. 
To further the analysis, we have grouped the processes into five categories: (1) "selection and design of measures", this category comprises the processes of identifying stakeholders needs and wants, planning, strategic objectives specification, measures design and selection and target setting; (2) "collection and manipulation of data", this category includes the processes of data capture and data analysis; (3) "information management", this category encompasses the processes of information provision, interpretation, decision making; (4) "performance evaluation and rewards", this category includes the processes of evaluating performance and linking it to rewards; and (5) "system review", this category includes the different review procedures (these procedures will ensure that there is a feedback loop within the system). All these processes can take place at either organisational, team or individual levels.

Researchers need to bear in mind that when they specify the features, roles and processes present in the BPM system they are studying, these specifications will define the boundaries of the system, and hence the research being undertaken. The greater the number of features, roles or processes to be included in the definition, the more difficult it will be to distinguish performance measurement from other management processes, especially performance management.

\section{Limitations}

This research has looked at aspects of BPM systems that researchers have explicitly mentioned in their definitions, and it has been conducted by a team of eight researchers, all of them with recognised knowledge and experience in the field of business performance measurement. However, using this type of method for identifying the main characteristics of a BPM system also creates some limitations. Firstly, we have only looked at explicit definitions 
of BPM systems. Although we cannot claim to have developed the complete list of features, roles and processes that a BPM system comprises, we have developed a very comprehensive list of BPM system characteristics that researchers could use to define the boundaries of their studies and make their work more transparent and comparable. Secondly, by only considering the definitions created by authors, rather than the meaning of their work as a whole, we missed much of the nuances provided by each paper. A more holistic approach, albeit necessarily more subjective, may provide greater insights. Further research on this area could improve the robustness of our results.

\section{Conclusions}

Issues related to comparability and generalisability of research have to be addressed if we want to make the field of performance measurement more relevant to theory and practice. As we have shown in this paper, researchers have been looking at BPM systems, often without explicitly describing the specific aspects of the BPM system under study. In the literature it is somehow assumed that the phrase BPM system is univocal. However, as we have shown, there is no consensus about the meaning of this phrase, and this situation creates confusion and inhibits the development of the field. Therefore, we suggest that researchers need to be more specific and explicit about the characteristics of the performance measurement systems they investigate. To start doing so, we have reviewed a number of definitions of BPM systems found in the literature, and we have discussed several characteristics of a BPM system from which researchers can choose for their studies. With this list of conditions, we hope to encourage a central debate within the performance measurement field, and to achieve greater level of clarity in future studies. 


\section{Acknowledgements}

We thank the EPSRC for support of this project through the research grants: Managing through Measures (grant number GR/R56136/01), Evaluating the Impact of Performance Measurement Systems (grant number GR/S28846) and Predictive Performance Measurement: Taking Control of Business Processes (grant number IMRC29),

\section{References}

Atkinson, A.A. (1998), "Strategic Performance Measurement and Incentive Compensation", European Management Journal, Vol. 16, No. 5, Oct, pp. 552-561.

Atkinson, A.A., Waterhouse, J.H. and Wells, R.B. (1997), "A Stakeholder Approach to Strategic Performance Measurement”, Sloan Management Review, Vol. 38, No. 3, pp. 2537.

Bititci, U.S., Carrie, A.S. and Mcdevitt, L. (1997), "Integrated Performance Measurement Systems: a Development Guide", International Journal of Operations \& Production Management, Vol. 17, No. 5-6, pp. 522-534.

Bourne, M. C. S., Neely, A. D., Mills, J. F. \& Platts, K. W, (2003), "Implementing performance measurement systems: a literature review", International Journal of Business Performance Management, Vol. 5, No. 1, 1-24.

Brennan, Andrew (2003), Necessary and Sufficient Conditions, The Stanford Encyclopedia of Philosophy, Edward N. Zalta (ed.), Available at http://plato.stanford.edu/archives/fall2003/ entries/necessary-sufficient/>.

Checkland, P. (1999), Systems Thinking, Systems Practice, John Wiley and Sons

Deming, W. E. (1982), Quality, Productivity, and Competitive Position. Cambridge, MA: MIT Center for Advanced Engineering Study.

Dumond, E.J. (1994), "Making Best Use of Performance-Measures and Information", International Journal of Operations \& Production Management, Vol. 14, No. 9, pp. 16-31.

Drucker, P.F. (1954), The Practice of Management, New York: Harper and Row Publishers, Inc

Forza, C. and Salvador, F. (2000), "Assessing Some Distinctive Dimensions of Performance Feedback Information in High Performing Plants", International Journal of Operations \& Production Management, Vol. 20 , No. 3, pp. 359-385.

Franco-Santos, M. and Bourne, M. (2005), "An examination of the literature relating to issues affecting how companies manage through measures, Production, Planning and Control, Vol. 16, No. 2, pp. 114-124.

Franco-Santos, M.; Bourne, M. and Neely, A. (2003), Understanding strategic performance measurement systems and their impact on organisational outcomes: a systematic review, Working paper Cranfield School of Management.

Feurer, R. and Chaharbaghi, K. (1995), "Dynamic strategy formulation and alignment". Journal of General Management, Vol. 20, No. 3, pp. 76-90.

Gates, S. (1999), Aligning Strategic Performance Measures and Results, The Conference Board, New York.

Goold, M. and Quinn, J.J. (1990), “The Paradox of Strategic Controls", Strategic Management Journal, Vol. 11, No. 1, pp. 43-57.
Deleted: We thank the EPSRC for support of this project through the research grants: Managing through Measures (grant number GR/R56136/01) and Evaluating

the Impact of Performance

Measurement Systems (grant number GR/S28846). 
Ittner, C., Larcker, D. and Randall, T. (2003), "Performance Implications of Strategic Performance Measurement in Financial Service Firms", Accounting, Organizations and Society, Vol.28, No.7-8, pp.715-741.

Johnson, H.T. and Kaplan, R.S. (1987), Relevance Lost: The Rise and Fall of Management Accounting, Harvard Business School Press, Boston, MA.

Kaplan, R.S. (1983), "Measuring Manufacturing Performance: A New Challenge for Accounting Research", The Accounting Review, Vol. 58, pp. 686-705.

Kaplan, R.S. and Norton, D.P. (1996), "Linking the Balanced Scorecard to Strategy (Reprinted From the Balanced Scorecard)", California Management Review, Vol. 39, No. 1, pp. 5379.

Kennerley, M. and Bourne, M. (2003), Assessing and maximising the impact of measuring business performance, Proceedings of the POMS/EurOMA Conference, Cernobbio, Lake Como, Italy, 16 - 18 June 2003, pp 493 - 502.

Kerssens-Van Drongelen, I. C. and Fisscher, O. A. M. (2003), "Ethical Dilemmas in Performance Measurement”, Journal of Business Ethics, 45 (1-2), 51-63.

Klir, G.J. (1991), Facets of Systems Science, Kluwer Academic

Lebas, M.J. (1995), "Performance Measurement and Performance Management", International Journal of Production Economics, Vol. 41, No. 1-3, pp. 23-35.

Lynch, R.L. and Cross, K.F. (1991), Measure Up - The Essential Guide to Measuring Business Performance, Mandarin, London.

Maisel, L.S. (2001), Performance Measurement Practices Survey Results, AICPA, US,

Marion, R. (1999), The edge of organization: chaos and complexity theories of formal social systems, Sage, USA.

Marr, B. and Schiuma, G. (2003), "Business Performance Measurement - Past, Present, and Future", Management Decision, Vol. 41, No. 8, pp. 680-687.

McGee, J.V. (1992), What Is Strategic Performance Measurement?, Ernst \& Young Center for Business Innovation, Boston, MA.

Neely, A.D. (1998), Measuring Business Performance: Why, What and How, The Economist and Profile Books Ltd., London, UK.

Neely, A.D. (2002), Business Performance Measurement: Theory and Practice, Cambridge University Press, Cambridge, UK.

Neely, A.D., Mills, J.F., Platts, K.W., Richards, A.H., Gregory, M.J., Bourne, M.C.S. and Kennerley, M.P. (2000) "Performance Measurement Systems Design: Developing and Testing a Process Based Approach", International Journal of Operations and Production Management, 20, 10, 1119-1146.

Neely, A.D., Gregory, M.J. and Platts, K. (1995), "Performance Measurement System Design: a Literature Review and Research Agenda”, International Journal of Operations \& Production Management, Vol. 15, No. 4, pp. 80-116.

Otley, D.T. (1999), "Performance Management: a Framework for Management Control Systems Research", Management Accounting Research, Vol. 10, No. 4, Dec, pp. 363-382.

Pfeffer and Sutton, (2006), Hard facts, dangerous half-truths, and total nonsense, Harvard Business School Press.

Rogers, S. (1990), Performance Management in Local Government, Longman, London, UK.

Rousseau (2006), "Is There Such a Thing as 'Evidence Based Management' ", Academy of Management Review, Vol. 31, No. 2, pp. 256-269

Senge, Peter M. 1990. The Fifth Discipline: The Art and Practice of the Learning Organization. New York: Doubleday.

Sim, K.L. and Koh, H.C. (2001), "Balanced Scorecard: a Rising Trend in Strategic Performance Measurement”, Measuring Business Excellence, Vol. 5, No. 2, pp. 18-27 
Smith, P.C. and Goddard, M. (2002), "Performance Management and Operational Research: a Marriage Made in Heaven?", Journal of the Operational Research Society, Vol. 53, No. 3, pp. 247-255. 